\title{
FAECAL BLOOD LOSS DURING TREATMENT WITH IBUFENAC, A NEW ANALGESIC DRUG
}

BY

G. R. TUDHOPE

Senior Lecturer in Therapeutics, University of Sheffield, and Consultant Physician, United Sheffield Hospitals

Aspirin is a drug of great value, especially in the treatment of chronic rheumatic conditions, but many studies have shown that there is an association between the ingestion of aspirin and gastro-intestinal haemorrhage (Muir and Cossar, 1955; Lange, 1957; Alvarez and Summerskill, 1958; Stubbé, 1958). Using ${ }^{51}$ Chromium to measure faecal blood loss, Scott, Porter, Lewis, and Dixon (1961) found that aspirin caused bleeding in 70 per cent. of patients tested; furthermore, various aspirin preparations, including its soluble salts and the complexes with organic molecules, also caused alimentary bleeding (Wood, Harvey-Smith, and Dixon, 1962).

In comparing the clinical usefulness of any new analgesic drug with that of aspirin, it is clearly necessary to assess the tendency to produce alimentary bleeding.

This report is concerned with measurements of faecal blood loss during the administration of the new analgesic drug, Ibufenac (4, isobutylphenylacetic acid), clinical trials of which have been reported by Chalmers (1963).

\section{Procedure}

The loss of blood from the alimentary tract was estimated by measuring the faecal radioactivity after previously labelling the patient's erythrocytes with $100 \mu \mathrm{c} .{ }^{51}$ chromium (Bannerman, 1957; Hughes Jones, 1958; Tudhope, 1958). Faecal collections were started 48 hours after the injection of the labelled cells. Each 24-hour stool collection was homogenized with water and weighed, and three aliquots, each of $5 \mathrm{ml}$, were taken in plastic tubes. The radioactivity of these samples was measured in a well-type scintillation counter and the total radioactivity in the 24-hour stool collection was calculated. Blood samples were taken at intervals of 3 to 7 days during the period of the study and the radioactivity of each sample was determined, after haemolysis by saponin. The quantity of whole blood which contained the same amount of radioactivity as was present in the 24-hour stool collection was regarded as the faecal blood loss in 24 hours. Sufficient counts of samples and background were obtained so that $2 \mathrm{ml}$. blood in a 24-hour collection of faeces of average bulk was measured with a statistical counting error of not more than \pm 10 per cent. (coefficient of variation).

The faecal blood loss during administration of Ibufenac was studied in eleven patients who required a mild analgesic of the aspirin type. Four had rheumatoid arthritis and two had osteo-arthritis; the remaining five suffered from ankylosing spondylitis, disseminated lupus erythematosus, ovarian carcinoma, bronchial carcinoma, and essential hypertension respectively.

In five cases, faecal blood loss during Ibufenac therapy was compared with that during aspirin administration, and in five with that during paracetamol therapy. In six patients blood loss was also measured during a control period when no drugs were given. The administration of each drug and the control period were each continued for 7 days, and the average daily faecal blood loss attributed to each drug was calculated from the total blood loss during 7 days, commencing 24 hours after the first dose of the drug.

The total daily dose of each drug, given orally in four divided doses at 6-hourly intervals, was as follows: Ibufenac $2 \mathrm{~g}$.; aspirin $2.5 \mathrm{~g}$; ; paracetamol 4 to $6 \mathrm{~g}$.

\section{Results}

The faecal blood loss during each 7-day period in ten patients with no known lesion of the alimentary tract is shown in the Table (opposite). When no drug was taken, the ${ }^{51}$ chromium content of the stools was equivalent to a daily blood loss of less than $2 \mathrm{ml}$. Faecal radioactivity during the control period of no drug therapy was compared with that during Ibufenac administration in Cases 1 to 6 . There was no significant difference in the apparent blood loss in five cases (Nos. 2 to 6 ), but in Case 1 the ${ }^{51}$ chromium content of the stools was significantly greater during Ibufenac therapy than in the control period, although the equivalent volume of blood lost was small (mean $2 \cdot 3 \mathrm{ml}$./day).

In four cases, no control period without drugs was possible. The effects of paracetamol and of Ibufenac therapy were compared in Cases 9 and 10, and in both the ${ }^{51}$ chromium content of the stools was equivalent to a blood loss of less than $2 \mathrm{ml}$./day. In Case 7, the faecal blood loss during Ibufenac therapy $(2.5 \mathrm{ml}$./day) was slightly greater than that with paracetamol. In Case 8, the blood loss during Ibufenac therapy $(2.6 \mathrm{ml}$./day) was similar to that with paracetamol $(2.4 \mathrm{ml}$./day). This patient had disseminated lupus erythematosus with thrombocytopenia; although no haemorrhagic manifestations 
TABLE

FAECAL BLOOD LOSS DURING 7-DAY PERIODS OF TREATMENT WITH IBUFENAC, ASPIRIN, AND PARACETAMOL AND WITHOUT DRUG THERAPY IN TEN PATIENTS WITH NO KNOWN ALIMENTARY LESION. THE MEAN BLOOD LOSS AND ALSO (IN BRACKETS) THE MAXIMUM 24-HOUR LOSS DURING EACH PERIOD ARE SHOWN

\begin{tabular}{|c|c|c|c|c|c|c|c|c|c|c|}
\hline \multirow{3}{*}{$\begin{array}{c}\text { Case } \\
\text { No. } \\
1\end{array}$} & \multirow{3}{*}{$\begin{array}{c}\begin{array}{c}\text { Age } \\
\text { (yrs) }\end{array} \\
49\end{array}$} & \multirow{3}{*}{$\begin{array}{c}\text { Sex } \\
\text { F }\end{array}$} & \multirow{2}{*}{\multicolumn{4}{|c|}{ Diagnosis }} & \multicolumn{4}{|c|}{ Faecal Blood Loss (ml./24 hrs) } \\
\hline & & & & & & & \multirow{2}{*}{$-\frac{\text { No Drug }}{1 \cdot 0(1 \cdot 7)}$} & \multirow{2}{*}{$\begin{array}{l}\text { Ibufenac } \\
2 \cdot 3(3 \cdot 6)\end{array}$} & \multirow{2}{*}{$\frac{\text { Aspirin }}{-}$} & \multirow{2}{*}{ Paracetamol } \\
\hline & & & Ovarian carcinoma & $\cdots$ & . & $\cdots$ & & & & \\
\hline 2 & 50 & $\mathbf{M}$ & Hypertension & $\cdots$ & $\cdots$ & $\cdots$ & $1 \cdot 2(1 \cdot 5)$ & $1 \cdot 9(2 \cdot 1)$ & - & - \\
\hline 3 & 50 & $\mathbf{F}$ & Osteo-arthritis & $\cdots$ & $\cdots$ & $\cdots$ & $0 \cdot 4(0 \cdot 7)$ & $0 \cdot 4(2 \cdot 1)$ & - & 一 \\
\hline 4 & 62 & $\mathbf{M}$ & Bronchial carcinoma & $\cdots$ & $\cdots$ & $\cdots$ & $1 \cdot 1(1 \cdot 4)$ & $1 \cdot 0(2 \cdot 8)$ & $3 \cdot 2(6 \cdot 0)$ & - \\
\hline 5 & 52 & $\mathbf{F}$ & Rheumatoid arthritis & $\cdots$ & $\cdots$ & $\cdots$ & $0 \cdot 6(1 \cdot 0)$ & $0.9(1 \cdot 3)$ & $1 \cdot 7(5 \cdot 3)$ & 一 \\
\hline 6 & 55 & $\mathbf{F}$ & Rheumatoid arthritis & $\cdots$ & $\cdots$ & $\cdots$ & $0.5(0.9)$ & $0 \cdot 5(1 \cdot 0)$ & $1 \cdot 5(2 \cdot 2)$ & $0.9(2 \cdot 0)$ \\
\hline 7 & 48 & $\mathbf{F}$ & Rheumatoid arthritis & $\cdots$ & . & $\cdots$ & - & $2 \cdot 5(3 \cdot 0)$ & $4 \cdot 4(9 \cdot 9)$ & $1 \cdot 2(2 \cdot 2)$ \\
\hline 8 & 50 & $\mathbf{F}$ & Disseminated lupus er & hem & sus & . & - & $2 \cdot 6(4 \cdot 0)$ & $4 \cdot 2(5 \cdot 9)$ & $2 \cdot 4(3 \cdot 7)$ \\
\hline 9 & 71 & $\mathbf{M}$ & Osteo-arthritis & $\cdots$ & $\cdots$ & $\cdots$ & - & $1 \cdot 3(*)$ & - & $1 \cdot 2(*)$ \\
\hline 10 & 62 & $\mathbf{F}$ & Rheumatoid arthritis & $\ldots$ & . & $\ldots$ & - & $0 \cdot 6(1 \cdot 7)$ & - & $1 \cdot 6(2 \cdot 2)$ \\
\hline
\end{tabular}

* In this case 7-day stool collections were bulked and values for individual days were not obtained.

were evident at the beginning of the ${ }^{51}$ chromium study, purpura appeared one week after completing these observations and it appears probable that the thrombocytopenia contributed to the alimentary blood loss in this case.

The blood loss during aspirin administration was considerably greater than during Ibufenac therapy; three of the five patients who received aspirin had an average faecal blood loss of more than $3 \mathrm{ml}$./day, and four had a loss of over $5 \mathrm{ml}$. in at least one 24-hour period.

During paracetamol administration no significant blood loss occurred except in the case of disseminated lupus erythematosus with thrombocytopenia (Case 8), which has already been discussed.

Apart from these studies in patients without gastro-intestinal lesions, Ibufenac was also given to a 38-year-old man who had ankylosing spondylitis and duodenal ulceration, who had been treated with aspirin for several months. He suffered severe ulcer symptoms and had a moderate degree of iron deficiency anaemia (haemoglobin $8.9 \mathrm{~g}$./ $100 \mathrm{ml}$.). During 7 days when aspirin therapy was continued, the faecal blood loss was $11 \cdot 1-23 \cdot 2 \mathrm{ml}$./ day (mean 18.4 ml.). When Ibufenac was substituted for aspirin there was an immediate reduction in faecal bleeding, and during the next 7 days the stools contained 6.5 to $9.3 \mathrm{ml}$./day (mean $8 \mathrm{ml}$.); when Ibufenac was replaced by aspirin after one week, there was again an increase in blood loss.

Although this study was carried out primarily to assess gastro-intestinal bleeding during Ibufenac therapy, in each case in which Ibufenac was compared with aspirin and/or paracetamol the patient was asked to state which analgesic he preferred. The nature of each drug was not divulged to the patients, but they were aware that different types of tablets had been given during each period of 7 days. Three patients with rheumatoid arthritis (Cases 5,6 , and 7) preferred Ibufenac to aspirin, and one (Case 10) preferred Ibufenac to paracetamol. Three other patients (Cases 4, 8, 9) detected no greater relief of symptoms with Ibufenac than with aspirin or paracetamol.

\section{Discussion}

The use of ${ }^{51}$ chromium provides the most satisfactory quantitative technique for the measurement of faecal blood loss (Owen, Bollman, and Grindlay, 1954; Roche, Perez-Gimenez, Layrisse, and Di Prisco, 1957; Bannerman, 1957; Ebaugh, Clemens, Rodnan, and Peterson, 1958). This method has been applied to measurements of alimentary bleeding produced by aspirin and other drugs (Scott and others, 1961 ; Grossman, Matsumoto, and Lichter, 1961 ; Pierson, Holt, Watson, and Keating, 1961; Wood and others, 1962). Most workers with this technique have found that, following the injection of ${ }^{51} \mathrm{Cr}$-labelled red cells, the apparent blood content of the stools in normal subjects and in patients without known source of alimentary bleeding who were not taking drugs of the salicylate type, was 1 to $2 \mathrm{ml}$. per day (Roche and others, 1957; Ebaugh and others, 1958; Grossman and others, 1961). Whether this value indicates actual loss of red cells into the alimentary tract, or leakage of ${ }^{51}$ chromium only is not certain. Scott and others (1961), in studying the blood loss produced by drugs, interpreted ${ }^{51} \mathrm{Cr}$ radioactivity in stools as indicative 
of bleeding associated with the drug, when it was equivalent to an average daily blood loss of more than $2 \mathrm{ml}$., or to more than $5 \mathrm{ml}$. on any one day.

Considerably less alimentary blood loss occurred with Ibufenac than with aspirin. In most cases in the present study there was no abnormal blood loss attributable to Ibufenac. However, in two patients, the ${ }^{51} \mathrm{Cr}$ content of the stools was slightly greater during Ibufenac therapy than with paracetamol or during the control period. This very slight degree of blood loss is, in itself, of little clinical importance. Whether this has any significance in relation to the possibility of the drug producing occasional massive haemorrhage, as with aspirin, cannot be answered from this study.

\section{Summary}

Measurements of alimentary blood loss during treatment with Ibufenac, a new analgesic drug, have been made by the ${ }^{51}$ chromium technique. Ten patients with no known gastro-intestinal lesion received Ibufenac for 7 days and in seven of them no significant alimentary bleeding occurred; one patient, who had thrombocytopenia, showed slight blood loss of similar degree during the administration of both Ibufenac and paracetamol; in the other two cases blood loss, of very slight degree occurred during Ibufenac therapy. Faecal blood loss was considerably less with Ibufenac than with aspirin.

One other patient, who had duodenal ulceration and who was actively bleeding at the start of the study, showed much less blood loss with Ibufenac than with aspirin.

I wish to thank Dr. E. V. B. Morton of Boots Pure Drug Co., Ltd., for the supply of Ibufenac ("Dytransin").

I gratefully acknowledge a grant towards the purchase of radio-isotopes from the Endowment Fund of the United Sheffield Hospitals.

\section{REFERENCES}

Alvarez, A. S., and Summerskill, W. H. J. (1958). Lancet, 2, 920.

Bannerman, R. M. (1957). Brit. med. J., 2, 1032.

Chalmers, T. M. (1963). Ann. rheum. Dis., 22, 358.

Ebaugh, F. G., Clemens, T., Rodnan, G., and Peterson, R. E. (1958). Amer. J. Med., 25, 169.

Grossman, M. I., Matsumoto, K. K., and Lichter, R. J. (1961). Gastroenterology, 40, 383.
Jones, N. C. Hughes (1958). Brit. med. J., 1, 493.

Lange, H. F. (1957). Gastroenterology, 33, 770.

Muir, A., and Cossar, I. A. (1955). Brit. med. J., $2,7$.

Owen, C. A., Bollman, J. L., and Grindlay, J. H. (1954). J. lab. clin. Med., 44, 238.

Pierson, R. N., Holt, P. R., Watson, R. M., and Keating, R. P. (1961). Amer. J. Med., 31, 259.

Roche, M., Perez-Gimenez, M. E., Layrisse, M., and Di Prisco, E. (1957). J. clin. Invest., 36, 1183.

Scott, J. T., Porter, I. H., Lewis, S. M., and Dixon, A. St. J. (1961). Quart. J. Med., 30, 167.

Stubbé, L. T. F. L. (1958). Brit. med. J., 2, 1062.

Tudhope, G. R. (1958). Quart. J. Med., 27, 543.

Wood, P. H. N., Harvey-Smith, E. A., and Dixon, A. St. J. (1962). Brit. med. J., 1, 669.

\section{Sang fécal au cours du traitement par Ibufenac, médicament analgésique nouveau}

\section{RÉSUMÉ}

On a mesuré la perte sanguine alimentaire, à l'aide du ${ }^{51}$ chrome, au cours de traitement par Ibufenac, médicament analgésique nouveau. Dix malades, sans lésion gastro-intestinale a vérée, recevaient Ibuf-nac pendant 7 jours et chez 7 d'entre eux aucune hémorragie appréciable ne s'est produite; un malade, atteint de thrombocytopénie, accusa une légère perte sanguine, d'un ordre similaire pendant l'administration d'Ibufenac que pendant l'administration de paracétamol; dans les deux autres cas une perte de sang très faible survint pendant la thérapie à Ibufenac. Le méléna fut considérablement moindre avec Ibufenac qu'avec l'aspirine.

Un autre malade, souffrant d'une ulcération duodénale et saignant activement au début de cette étude, perdait beaucoup moins de sang avec Ibufenac qu'avec l'aspirine.

Pérdida de sangre fecal durante el tratamiento con Ibufenac, un nuevo analgésico

\section{SUMARIO}

Se midió la pérdida alimenticia de sangre, con la ayuda de ${ }^{51}$ cromio, durante el tratamiento con Ibufenac, un nuevo analgésico. Diez enfermos, sin conocida lesión gastro-intestinal, recibieron Ibufenac durante siete días. En siete de ellos no hubo melena apreciable; un enfermo sufriendo de trombocitopenia, acusó una leve pérdida sanguinea, de un grado similar a la que ocurrió durante la administración de paracetamol. En los demás dos casos la melena fué levísíma con Ibufenac. La pérdida sanguinea fecal con Ibufenac fué considerablemente menor que con aspirina.

Un otro enfermo, con ulceración duodenal y sangrando al principio de esta investigación, perdió mucho menos sangre con Ibufenac que con aspirina. 